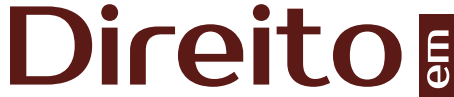 \\ Debate
}

Revista do Departamento de Ciências Jurídicas e Sociais da Unijuí

Editora Unijuí - Ano XXX - n. 56 - jul./dez. 2021 - ISSN 2176-6622

\section{TEORIA DA DESCONTAMINAÇÃO NA JURISDIÇÃO SUSTENTÁVEL E PROVA ILÍCITA ${ }^{1}$}

http://dx.doi.org/10.21527/2176-6622.2021.56.10029

Recebido em: 27/12/2019

Aceito em: 29/7/2020

Magno Federici Gomes

Autor correspondente. Escola Superior Dom Helder Câmara - Mestrado em Direito Ambiental e Desenvolvimento Sustentável. Rua Álvares Maciel, 628 - Santa Efigênia. Belo Horizonte/MG, Brasil. CEP 30150-250. http://lattes.cnpq.br/1638327245727283. https://orcid.org/0000-0002-4711-5310. federici@pucminas.br

Letícia Alves de Oliveira

Pontifícia Universidade Católica - PUC Minas. Belo Horizonte/MG, Brasil.

\section{RESUMO}

O presente estudo busca discutir a contaminação do julgador pelo contato com a prova ilícita, que afeta profundamente seu convencimento e sua imparcialidade. Percebe-se que as provas ilícitas são prejudiciais para a imparcialidade do julgador, que afeta tanto os demandantes quanto a própria aplicação do Direito. Deste modo, busca-se compreender como ocorre a contaminação do julgador pelo contato com a prova ilícita e quais são as consequências desse fenômeno ao processo civil. Utilizou-se no trabalho a metodologia teórico-documental, com raciocínio dedutivo. Conclui-se que a contaminação do juiz pela prova ilícita acarreta a sua suspeição, causando nulidade relativa ao processo. Palavras-chave: Provas ilícitas; princípios; imparcialidade; contaminação do juiz; suspeição.

\section{DECONTAMINATION THEORY IN SUSTAINABLE JURISDICTION AND ILLEGAL EVIDENCE}

\section{ABSTRACT}

This paper seeks to discuss the contamination of the judge by contact with the illicit evidence, which profoundly affects his conviction and his impartiality. It appears that unlawful evidence is detrimental to the impartiality of the Court, which affects both the plaintiffs and the actual application of the law. In this way, it is sought to understand how the contamination of the judge occurs by the contact with the illicit evidence, and what are the consequences of this phenomenon to the civil process. The theoretical-documentary methodology was used in the paper, with deductive reasoning. It is concluded that the contamination of the judge by the unlawful evidence causes his suspicion, producing relative nullity to the procedure.

Keywords: Unlawful evidence; principles; impartiality; contamination of the judge; suspicion. 


\section{INTRODUÇÃO}

O direito à prova é um direito fundamental, destacando-se que as provas detêm diversas funções no processo judicial. Em razão disso, significativa é sua importância, contribuindo para a formação do convencimento do julgador e ainda tem o papel de legitimar a própria decisão judicial. Diversas, no entanto, são as questões relevantes em torno das provas, principalmente com relação a sua correta obtenção e utilização no processo, como é o caso das provas ilícitas.

O problema que se pretende responder é como solucionar a questão da contaminação do julgador pelo contato com a prova ilícita, que é um tipo de propensão cognitiva e que afeta profundamente seu convencimento, chegando às margens da parcialidade.

Com isso, o objetivo deste estudo é discutir a prova ilícita e suas consequências dentro do processo civil. Busca-se, então, fornecer meios para combater o dilema antes apresentado. Ademais, é de suma importância o estudo da contaminação do julgador pela prova ilícita e das questões em torno do assunto, em razão do papel fundamental da imparcialidade para as decisões judiciais no Estado Democrático de Direito.

Utilizou-se no trabalho a metodologia teórico-documental, com técnica dedutiva e consulta a fontes bibliográficas, tendo como marco teórico a obra de Marinoni, Arenhart e Mitidiero (2016).

Este estudo analisará os princípios constitucionais no processo civil inerentes ao tema. Após, estudará as provas, inclusive as ilícitas, e as vedações constitucional e legal relativas ao objeto de pesquisa. Depois, passará ao tratamento da prova ilícita e do dever de imparcialidade dos magistrados, inclusive os institutos do impedimento e da suspeição, até chegar à contaminação, ou não, do juiz, pela prova ilícita.

\section{PRINCÍPIOS CONSTITUCIONAIS DO PROCESSO CIVIL INERENTES AO TEMA}

Os princípios são extremamente importantes para o Direito e norteiam o ordenamento jurídico brasileiro, sendo essenciais para a própria aplicação do Direito. Em destaque, os princípios constitucionais, que estão expressos na Constituição Federal de 1988 (CF/88), que têm especial relevância no processo civil.

Além disso, os princípios "são tidos como preceitos fundamentais para a prática do Direito e proteção aos direitos" (SILVA, 1993, p. 447). Assim, os princípios são essenciais para o exercício do Direito e servem para a própria defesa desses princípios contra arbitrariedades.

Com relação ao tema da contaminação do juiz pela prova ilícita, tem-se como princípios inerentes ao tema os princípios da isonomia, juízo natural, devido processo legal, contraditório e proibição de provas ilícitas.

O princípio da isonomia objetiva o tratamento igualitário das partes processuais, mediante a subordinação destas às mesmas regras jurídicas, para que tenham iguais oportunidades durante todo o processo, e tenham, principalmente, igualdade quanto à produção e análise de provas.

Já o princípio do juízo natural relaciona-se ao requisito constitucional da ordinariedade do juízo, que dispõe que este seja estabelecido anteriormente ao fato que será julgado, o que impede o tratamento díspar entre os casos no poder Judiciário, observando-se que ao poder Judiciário incumbe "a importante missão constitucional de promover o tratamento dos conflitos, sempre objetivando assegurar e harmonizar dialeticamente a fruição dos direitos fundamentais e imputar o respeito e o cumprimento dos deveres fundamentais" (BODNAR, 2009, p. 112). Assim, compete ao poder Judiciário a resolução dos conflitos e a proteção do Direito, sendo essencial a ordinariedade do juízo para alcançar tais fins, uma vez que este princípio promove a igualdade e protege os direitos das partes, revelando-se uma garantia para partes no processo.

O devido processo legal assegura que as decisões estejam de acordo com o texto constitucional. Assim, todas as decisões judiciais devem estar em conformidade com a Constituição Federal, respeitando os direitos fundamentais, e, mais do que isso, ninguém pode ser julgado e privado de um direito fundamental sem que possa se defender.

O princípio do contraditório consiste em uma garantia de influência e não surpresa das partes no processo, que promove a real participação das partes no processo, que influencia a formação do convencimento do magistrado e contribui para a decisão judicial. 
Por fim, o princípio da vedação das provas ilícitas consiste no direito das partes de não terem no processo provas ilícitas produzidas ou provas obtidas ilicitamente. Ressalta-se que todas as provas contrárias à norma do ordenamento jurídico são consideradas ilícitas e não poderão ser utilizadas no processo. Assim, não foram estabelecidas restrições para a proibição da prova ilícita, e ocorrendo colisão entre direitos fundamentais necessita-se de ponderação entre os direitos no caso concreto.

\section{PROVAS}

O direito fundamental à prova está disposto no artigo $5^{\circ}$, inciso $\mathrm{LV}, \mathrm{da} \mathrm{CF} / 88$, a qual tem extrema importância no processo judicial, uma vez que "contribui para a formação do convencimento do julgador acerca da lide" (NUNES et al., 2013, p. 222).

Deste modo, percebe-se que a prova é essencial no processo, que não se limita apenas às partes, mas contribui para a formação do convencimento do julgador, e ainda tem o papel de legitimar a própria decisão judicial.

Destaca-se que a palavra prova tem significados distintos no processo judicial, que variam conforme o contexto em que o termo é empregado, podendo significar os meios para a ciência dos fatos pelo magistrado, o procedimento de formação e recepção dos instrumentos de cognição pelo juízo, a atividade lógica do juiz para compreensão dos fatos, ou ainda, o fruto dessa atividade lógica (MARINONI; ARENHART; MITIDIERO, 2016, p. 257). Apesar dos diversos significados, todos destinam-se à formação do convencimento do juiz.

Importante salientar que a concepção de prova também está ligada à "racionalização da descoberta da verdade" (MARINONI; ARENHART; MITIDIERO, 2016, p. 250). A prova, contudo, não busca apenas a verdade, como dispõem Nunes et al.:

Isso significa que a prova não busca a "verdade", mas, sim, a demonstração que os fatos narrados na petição inicial e na defesa são ou não comprováveis, o máximo que se viabiliza mediante o debate processual é um "alto grau de probabilidade" (NUNES et al., 2013, p. 223).

Desse modo, a prova busca não apenas a descoberta da verdade, mas comprovar os fatos alegados pelas partes durante o processo. Com isso, é possível perceber o papel da prova no processo, que tem por objetivo a comprovação das alegações das partes, o que colabora para o convencimento do julgador. Importantes considerações fazem Didier Jr., Braga e Oliveira sobre a finalidade da prova:

Além de ter por objetivo convencer o juiz acerca das alegações de fato sobre as quais se desenvolve a atividade probatória, a prova também tem por finalidade permitir que as próprias partes se convençam (i) de que efetivamente são titulares das situações jurídicas que, em princípio, pensam ter e (ii) da demonstrabilidade em juízo das alegações de fato subjacentes a tais situações jurídicas (2015, p. 50).

Assim, percebe-se que o magistrado não é o único destinatário da prova, mas as partes, também, quanto ao seu convencimento sobre os direitos alegados.

Ainda, Nunes et al. enumeram as espécies de provas, que são: "o depoimento pessoal; confissão; exibição de documento ou coisa; prova documental; prova testemunhal; prova pericial e inspeção judicial" (NUNES et al., 2013, p. 225). Além destes, outros meios moralmente legítimos são admitidos para comprovar os fatos alegados pelas partes.

Há, contudo, fatos que independem de prova, quais sejam "I - notórios; II - afirmados por uma parte e confessados pela parte contrária; III - admitidos no processo como incontroversos e III - em cujo favor milita presunção legal de existência ou de veracidade", conforme o artigo 374 do Código de Processo Civil de 2015 (CPC/15) (BRASIL, 2015).

Destaca-se que o artigo 77 do $C P C / 15$, dispõe sobre os deveres das partes, em especial o inciso III, que estabelece como dever das partes "não produzir provas e não praticar atos inúteis ou desnecessários à declaração ou à defesa do direito" (BRASIL, 2015).

Nesse sentido, "um processo justo depende diretamente da ética entre as partes, de modo que demandante e demandado devem atuar com a lealdade processual que a lei exige, evitando dilações imprestáveis e 


\section{Direito \\ Debate}

TEORIA DA DESCONTAMINAÇÃO NA JURISDIÇÃO SUSTENTÁVEL E PROVA ILÍCITA

Magno Federici Gomes - Letícia Alves de Oliveira

procrastinações injustificáveis" (GOMES; FERREIRA, 2017, p. 115). Assim, as partes têm o dever de lealdade umas com as outras no processo, evitando condutas desonestas, alheias à defesa de seus direitos.

Além disso, o artigo 378 do CPC impõe o dever de colaboração às partes, quando estabelece que "ninguém se exime do dever de colaborar com o poder Judiciário para o descobrimento da verdade" (BRASIL, 2015). Dever esse que ganha destaque na produção de provas, uma vez que elas estão relacionadas à busca da verdade.

Ademais, as provas serão analisadas conforme o sistema de persuasão racional; o artigo 370 do CPC consagra o sistema de persuasão racional na apreciação da prova, sistema este que é intermediário entre o sistema da prova legal e o sistema da livre ou íntima convicção.

Ressalta-se que no sistema da prova legal a lei atribuía o valor da prova, e o juiz se vinculava a essas determinações; e no sistema da livre ou íntima conviç̧ão o juiz decidia livremente, sem necessidade de fundamentar sua decisão (GRECO FILHO, 2007, p. 236). Sobre o sistema de persuasão racional, Grinover, Fernandes e Gomes Filho destacam que

[...] o método do livre convencimento ou persuasão racional, o qual se cumpre pela valoração de todo o material probatório existente nos autos, e somente deste. Por ele o juiz forma livremente o seu convencimento, mas sem despotismo, porque a decisão há de ser fundamentada e só pode alicerçar-se sobre as provas existentes nos autos (2007, p. 143).

O sistema de persuasão racional permite a livre apreciação da prova, mas vincula tal apreciação aos fatos e circunstâncias contidos no processo, e, ainda, exige a indicação na decisão das razões da formação do seu convencimento.

Apesar da consagração do sistema de persuasão racional no $\mathrm{CPC} / 15$, há hipóteses em que se vislumbra a aplicação do sistema da prova legal, como nos artigos 442 e 443 do CPC/15, que dispõem sobre a admissibilidade da prova testemunhal e nos artigos 405 e 406, do mesmo diploma legal, sobre a fé de documentos públicos. E há, também, a aplicação do sistema da livre ou íntima convicção no caso dos julgamentos dos crimes dolosos contra a vida pelo tribunal do júri, conforme o artigo $5^{\circ}$, inciso XXXVIII, da CF/88.

Ademais, o sistema de persuasão racional é uma garantia constitucional do processo que assegura a justiça na apreciação da prova, e, principalmente, garante que a decisão seja baseada em elementos constantes no processo e que seja motivada.

Assim, evidencia-se o papel fundamental da prova no processo, que depende de todos os sujeitos processuais para atingir o fim almejado.

\subsection{Prova ilícita}

O direito fundamental à vedação de provas ilícitas, expresso no artigo 5으, inciso LVI, da CF/88, proíbe tanto as provas ilícitas quanto as provas obtidas ilicitamente. Didier Jr., Braga e Oliveira sobre provas ilícitas e provas obtidas ilicitamente, destacam:

Há quem distinga entre prova ilícita e prova obtida ilicitamente. Aquela seria a prova com conteúdo ilícito; esta, a prova cuja colheita ou método de inserção no processo é ilícito. Considera-se, porém, que ambas estão abrangidas pela vedação do art. $5^{\circ}$, inciso LVI, da Constituição Federal $(2015$, p. 95).

Diante disso, a definição de prova ilícita envolve todas as provas contrárias à norma do ordenamento jurídico, podendo a norma violada ser de qualquer natureza jurídica.

Como exemplos de provas ilícitas, Didier Jr., Braga e Oliveira citam "a confissão obtida sob tortura, o depoimento de testemunha sob coação moral, a interceptação telefônica clandestina, a obtenção de prova documental mediante furto, a obtenção de prova mediante invasão de domicílio, etc." (2015, p. 32).

Ainda há a prova moralmente ilegítima, vedada pelo artigo 369 do CPC/15, que seria contrária à boa-fé objetiva, essa constituindo uma norma jurídica ou um princípio. Deste modo, a prova seria ilícita por violar a boa-fé objetiva, e, por consequência, uma norma jurídica. 
Nunes et al. classificam a prova ilícita e a prova ilegítima como sendo espécies do gênero prova ilegal (2013, p. 222), a prova ilícita como sendo a prova obtida violando uma regra de direito material e a prova ilegítima violando uma regra de direito processual.

Destaca-se que o direito fundamental à vedação de provas ilícitas e o direito fundamental à prova são complementares, uma vez que "o direito à prova é limitado pela legitimidade dos meios utilizados para obtê-la" (DIDIER JR.; BRAGA; OLIVEIRA, 2015, p. 33). Tais direitos, contudo, poderão colidir quando houver apenas um meio de prova para comprovar as alegações feitas por uma parte, mas tal meio de prova seja considerado ilícito. Diante disso, o juiz deverá utilizar-se de uma ponderação entre os direitos, conforme o princípio da proporcionalidade.

Assim, excepcionalmente, as provas ilícitas poderão ser admitidas, mas, em regra, elas não podem ser utilizadas no processo, em razão da vedação constitucional, artigo $5^{\circ}$, inciso LVI, da CF/88, e legal, artigo 369, do $C P C / 15$, que serão analisadas a seguir.

\subsubsection{Vedação constitucional e vedação legal}

Como mencionado anteriormente, o artigo $5^{\circ}$, inciso $\mathrm{LVI}$, da $\mathrm{CF} / 88$ veda a utilização de provas obtidas por meios ilícitos, as quais são aquelas alcançadas mediante violação de uma regra de direito material.

Normalmente, tais provas "violam direitos fundamentais materiais, como os direitos à inviolabilidade da intimidade, da imagem, do domicílio e da correspondência (art. $5^{\circ}, \mathrm{X}, \mathrm{XI}$ e XII da CF)" (MARINONI; ARENHART; MITIDIERO, 2016, p. 326).

Assim, as provas ilícitas para serem obtidas violaram direitos fundamentais, o que é expressamente vedado pela CF/88. Dessa forma, em razão da violação de uma regra de direito material, as provas ilícitas não podem ser sanadas e, por consequência, não podem produzir efeitos no processo, o que é necessário para proteção dos direitos.

No caso, entretanto, de conflito entre princípios constitucionais de igual valor hierárquico, poderá ser aplicado o princípio da proporcionalidade:

Para corrigir possíveis distorções originadas da utilização do texto frio da lei ao caso concreto, recorre-se ao emprego do princípio da proporcionalidade. A regra da proibição da prova ilícita está inserida no título: "Dos Direitos e Garantias Fundamentais" da CR/88, pelo que deve ser vista como uma norma basilar protetiva do princípio da dignidade da pessoa humana. Todavia, no mesmo título, estão garantidos outros direitos igualmente importantes, como os direitos à liberdade, à vida, ao contraditório, à ampla defesa e à segurança, de modo que pode haver determinados casos em que dois princípios constitucionais de igual valor hierárquico conflitem.Em situações tais, propõe-se a aplicação do princípio da proporcionalidade, por meio do qual os bens ou valores igualmente protegidos constitucionalmente são sopesados, de modo a possibilitar que a proteção de um bem jurídico não implique na exclusão ou eliminação do outro (GOMES; DRUMOND, 2012, p. 29).

Assim, havendo conflito entre a regra da proibição da prova ilícita e direitos igualmente importantes, sendo princípios constitucionais de igual valor hierárquico, será utilizada a proporcionalidade para que seja aplicado o princípio mais adequado ao caso concreto para proteger o bem jurídico em questão, sem que elimine o princípio não aplicado. Marinoni, Arenhart e Mitidiero esclarecem que:

$\mathrm{O}$ art. $5^{\circ}$, inciso LVI, da CF não nega o direito à prova, mas apenas limita a busca da verdade, que deixa de ser possível através de provas obtidas de forma ilícita. $O$ interesse no encontro da verdade cede diante de exigências superiores de proteção dos direitos materiais que podem ser violados (2016, p. 327).

Assim, há a proibição das provas ilícitas para proteger o direito material, evitando que as partes busquem a qualquer custo provas para demonstrar as afirmações relacionadas aos fatos por elas alegados. Já o artigo 369 do $\mathrm{CPC} / 15$, sobre as provas, assim estabelece:

Art. 369 do CPC/15. As partes têm o direito de empregar todos os meios legais, bem como os moralmente legítimos, ainda que não especificados neste Código, para provar a verdade dos fatos em que se funda o pedido ou a defesa e influir eficazmente na convicção do juiz (BRASIL, 2015). 
Nesse dispositivo percebe-se a intenção do legislador em garantir o direito fundamental à prova, que apenas se limita à vedação das provas ilícitas, expressa no artigo $5^{\circ}$, inciso LVI, da CF/88, e moralmente ilegítimas, estabelecida no artigo anteriormente transcrito.

Assim, são permitidas as provas obtidas por "meios legais", ou seja, qualquer meio previsto em lei, e, ainda, meios "moralmente legítimos", que, apesar de não estarem previstos em lei, estão de acordo com o Direito. Nesse sentido, Marinoni, Arenhart e Mitidiero fazem importante esclarecimento:

Quando o art. 369 alude a meios moralmente legítimos, não está contrapondo o que é legal com o que é moral, mas sim dizendo que esses meios (moralmente legítimos) são aqueles que não estão expressamente tipificados em lei. Tais meios, dessa forma, são as provas atípicas (2016, p. 320).

Desse modo, os meios de prova deverão estar em concordância com o Direito, constituindo meios de provas legais, mas podem ou não estarem previstos em lei, podendo ser típicos ou atípicos. Ademais, o dispositivo em questão promove o direito fundamental à prova, mas ainda preza pela conformidade das provas com o Direito, assim protegendo o direito material. Dessa forma, a vedação constitucional e a vedação legal são essenciais para a proteção do direito material e para as decisões justas.

\subsubsection{0 tratamento da prova ilícita}

Apesar de o processo penal e do processo civil estarem submetidos à mesma vedação constitucional em relação às provas ilícitas (artigo $5^{\circ}$, inciso $\mathrm{LVI}$, da $\mathrm{CF} / 88$ ), diante das peculiaridades dos direitos processuais faz-se necessária uma análise separada quanto ao tratamento da prova ilícita.

A prova ilícita no processo penal tem relevante destaque, em razão de a obtenção de provas ser uma incumbência da polícia; por isso, faz-se necessário um mecanismo de controle da atuação policial para evitar a obtenção de provas mediante violação de normas.

Conforme artigo 157 do Código de Processo Penal (CPP), as provas ilícitas não podem ser utilizadas no processo, devendo ser desentranhadas, ainda que os fatos apurados sejam relevantes. Apesar de ser essa a teoria dominante, em situações excepcionais admite-se a aplicação da teoria da proporcionalidade, que admite a utilização de provas ilícitas apenas se, inadmitida a prova ilícita, isso provocasse resultados desproporcionais, ou seja, resultados mais graves que a ofensa ao direito material em virtude da utilização da prova ilícita (GRINOVER; FERNANDES; GOMES FILHO, 2006, p. 152).

Relacionada à aplicação do princípio da proporcionalidade, admite-se a utilização de provas ilícitas se favorável ao acusado, em razão do princípio da proporcionalidade ou mediante a aplicação das hipóteses de exclusão de ilicitude referentes ao Direito Penal, pois se eliminaria a ilicitude da prova por estar sendo utilizada em benefício do réu. $E$, ainda, a prova ilícita também poderá ser utilizada pela acusação, mas apenas quando a aplicação da vedação da prova ilícita provoque flagrante e notória injustiça, como nos crimes de racismo, tráfico de drogas, tortura, terrorismo e crime organizado (GOMES; DRUMOND, 2012, p. 30).

Além disso, merece especial destaque a teoria dos frutos da árvore venenosa (fruits of the poisonous tree), que origina o conceito das provas ilícitas por derivação, que, apesar de serem lícitas, foram produzidas a partir de provas ilícitas.

Quanto às provas ilícitas por derivação, o CPP, em seu artigo 157, parágrafos $1^{\circ}$ e $2^{\circ}$, estabelece exceções, se a prova ilícita não foi determinante para a obtenção da prova derivada ou se a prova deriva de fonte independente, poderá ser utilizada no processo.

De todo modo, o juiz deverá fundamentar sua decisão que admita no processo uma prova derivada, em razão do dever da fundamentação racional das decisões, estabelecido no artigo 93, inciso IX, da CF/88.

Por fim, observa-se que além do controle da atuação policial para se evitar condutas abusivas, a vedação a provas ilícitas no processo penal também tem como objetivo proteger o direito de liberdade diante do poder punitivo do Estado.

Por sua vez, no processo civil, além da proibição constitucional a provas ilícitas, artigo $5^{\circ}$, inciso LVI, da $\mathrm{CF} / 88$, o artigo 369 do CPC veda as provas moralmente ilegítimas, como mencionado em tópico anterior. 
E quanto à vedação a provas ilícitas, no processo civil ocorre a ponderação entre o "direito material que se deseja tutelar na forma jurisdicional e o direito material violado pela prova ilícita" (MARINONI; ARENHART; MITIDIERO, 2016, p. 331).

Assim, analisa-se a proporcionalidade entre os direitos, para então se decidir quanto ao destino da prova ilícita e sua possível utilização no processo. Nesse sentido, Gomes e Drumond argumentam

Finalmente, no ínterim do direito processual civil, de mesma forma, a prova ilícita poderá ser empregada em casos em que prevalece o interesse público indisponível,ou seja, quando favorecer a interesses de incapazes, nas causas sobre o estado da pessoa, poder familiar, tutela, curatela, interdição, declaração de ausência e nas ações que envolvam pretensões difusas ou coletivas, inclusive nas ações constitucionais dessa índole, tendo em vista o princípio da isonomia constante no art. 5, caput, da CR/88 e os demais direitos fundamentais presentes no mesmo dispositivo constitucional, desde que não seja possível a sua produção por outro meio admissível (2012, p. 30).

Com isso, verificando a proporcionalidade entre os direitos, a prova ilícita poderá ser utilizada em casos em que não seja possível produzi-la por outros meios.

Como mencionado, há exceções às provas ilícitas por derivação, dispostas no artigo 157, parágrafos $1^{\circ}$ e $2^{\circ}$, do CPP. Quando a prova ilícita não foi determinante para a obtenção da prova derivada, ou se a prova puder ser obtida a partir de fonte independente, poderá ser utilizada no processo.

Tais dispositivos podem ser aplicados por analogia ao Processo Civil, em razão do enunciado n. 301 do Fórum Permanente de Processualistas Civis, em que se estabeleceu que "aplicam-se ao processo civil, por analogia, as exceções previstas nos $\S \S 1^{\circ}$ e $2^{\circ}$ do artigo 157 do CPP, afastando a ilicitude da prova" (PEIXOTO, 2018, p. 42).

Desse modo, no processo civil promove-se a ponderação entre o direito material tutelado e o direito material violado pela prova ilícita, para que se obtenha decisões mais justas e adequadas.

\section{DA IMPARCIALIDADE COMO DEVER DO JUIZ}

O juiz para ser legítimo para a condução de um processo deve ser qualificado como juiz natural, direito fundamental expresso no artigo $5^{\circ}$, incisos XXXVII e LIII, da CF/88.

O juiz natural tem o dever de imparcialidade ao conduzir o processo, "que pode ser definida como a ausência de interesse pessoal na solução no caso concreto" (MARINONI; ARENHART; MITIDIERO, 2016, p. 81).

Assim, o magistrado, para ser considerado imparcial, não poderá ter interesse no processo que conduz, dado que qualquer tipo de interesse certamente comprometerá suas decisões.

Certo é que condição para a imparcialidade e isenção diante de pressões externas é a independência da magistratura, assegurada pelas garantias da vitaliciedade, inamovibilidade e irredutibilidade de subsídios, conforme o artigo 99, da CF/88. Greco Filho esclarece que

[...] é evidente que a imparcialidade é garantia essencial, porquanto a distribuição da justiça incorreria em grave risco se pudesse estar nas mãos de juiz pessoalmente interessado na causa. De um lado, haveria o prejuízo das partes, que poderiam ter uma sentença não conforme o direito, mas conforme o sentimento do magistrado, e, de outro, o prejuízo do interesse público na distribuição da justiça e na aplicação do direito (2007, p. 54).

Desse modo, a imparcialidade é essencial para a justiça das decisões, uma vez que a sua ausência, além de causar prejuízo às partes, também o faz em relação à aplicação do Direito.

Assim, Marinoni, Arenhart e Mitidiero esclarecem que "ser independente e imparcial é ser fiel ao Direito - vale dizer, desde o ponto de vista da administração da justiça, ser fiel à interpretação que lhe é conferida pelos tribunais para o caso concreto e a partir do caso concreto" (MARINONI; ARENHART; MITIDIERO, 2016, p. 82).

Assim entendido, o juiz imparcial deve ser fiel ao Direito e alheio ao processo que conduz, devendo considerar apenas o direito para julgar e não interesses pessoais. Dessa forma, Pegoraro Junior faz as seguintes considerações sobre a imparcialidade: 
A exigência da imparcialidade no âmbito do processo, assim, não se insere num contexto ideal de neutralidade absoluta, mas sim, a partir de critérios objetivos e subjetivos, de assegurar minimamente a imparcialidade do julgador e dos demais atores envolvidos na prestação jurisdicional, com suporte em mandamento constitucional e em tratados internacionais, impondo-se como um direito processual fundamental a um devido processo legal e justo (PEGORARO JUNIOR, 2017, p. 14).

Nesse contexto, a imparcialidade é um grande desafio para o magistrado, não podendo almejar a utópica neutralidade absoluta, que é impossível ao ser humano, mas buscando assegurar a imparcialidade a partir de critérios objetivos e subjetivos, como as hipóteses de impedimento e suspeição que acarretam o afastamento do juiz parcial.

Ademais, a imparcialidade é de suma importância para assegurar a correta aplicação do Direito. Em razão da imparcialidade, o CPC/15 prevê nos artigos 144 e 145 as hipóteses de impedimento e suspeição, que possibilitam o afastamento do juiz parcial, ou seja, aquele que é influenciado por fatores alheios ao direito das partes; trata-se, pois, de questões relativas ao próprio juiz e não ao Juízo.

Assim sendo, o impedimento e a suspeição ao afetarem a imparcialidade do juiz, por consequência, impedem a igualdade de tratamento das partes e a justiça das decisões.

As causas de impedimento estão dispostas no artigo 144, do CPC/15, e são circunstâncias objetivas que impedem o juiz de atuar no processo, ou por já ter atuado na causa ou por estar ligado intimamente à lide. Assim, as causas de impedimento proíbem o magistrado de exercer o poder jurisdicional no caso concreto.

Pegoraro Junior esclarece que "a índole que assume as hipóteses de impedimento tem caráter pessoal, afastando a pessoa física do juiz para o julgamento da causa, mas sem deslocar a competência do órgão jurisdicional" (2017, p. 14).

Percebe-se que as causas de impedimento são referentes à pessoa física do juiz, que não afetam a competência do órgão jurisdicional, pois são hipóteses retidas à pessoa do juiz que o impedem de julgar com imparcialidade, o que acarreta a proibição do magistrado de exercer sua função jurisdicional. Nesse sentido, Greco Filho dispõe que:

Nos casos em que a lei considera o juiz impedido, está ele proibido de exercer sua função jurisdicional. A violação dos casos de impedimento acarreta a nulidade do processo, gerando a possibilidade da ação rescisória se, apesar da proibição legal, o juiz impedido proferiu sentença que se tornou definitiva com o trânsito em julgado (art. 485, II) (2007, p. 241).

Assim, diante da gravidade das hipóteses de impedimento que acarretam a nulidade do processo, há possibilidade de rescisão da decisão proferida por juiz impedido, conforme o artigo 966, II, do CPC/15.

Destaca-se que as causas de impedimento, por comprometerem totalmente a imparcialidade do julgador, objetivam proteger interesses de ordem pública no processo, em razão disso acarretam nulidade absoluta, não podendo ser sanadas, o que justifica a possibilidade de tornar sem efeito a decisão proferida por juiz impedido.

Já as causas de suspeição estão dispostas no artigo 145 do CPC, e "são hipóteses em que o juiz ou está psicologicamente vinculado às partes ou tem interesse na solução da causa de seu cônjuge ou de parente deste em linha reta, ou na colateral até terceiro grau" (GRECO FILHO, 2007, p. 242).

Diferentemente das causas de impedimento, as causas de suspeição não proíbem o magistrado de exercer o poder jurisdicional, apenas se suscita uma dúvida quanto à sua imparcialidade, o que ocasiona o seu afastamento do processo. Não há possibilidade, no entanto, de rescisão da decisão proferida por juiz suspeito, pois as causas de suspeição acarretam tão somente nulidade relativa, não torna nula a sentença.

Desse modo, as causas de suspeição geram uma dúvida quanto à imparcialidade do juiz; assim a parte interessada deve arguir a nulidade relativa, pois se retém somente a ela eventuais prejuízos por atos praticados pelo juiz suspeito. Além disso, diferentemente das hipóteses de impedimento, as causas de suspeição não podem ser alegadas posteriormente ao trânsito em julgado da sentença. Dessa forma, se a parte não fizer a alegação na primeira oportunidade em se manifestar nos autos, o ato praticado pelo juiz suspeito será convalidado. 
O procedimento para reconhecer o impedimento e a suspeição está disposto no artigo 146 do CPC. Tais causas devem ser arguidas por qualquer das partes por meio de exceção, ou ser reconhecidas pelo próprio juiz de ofício, caso em que este remeterá o processo ao seu substituto legal. Nessa hipótese não cabe recurso, pois não há sucumbência para as partes.

Em caso contrário, conforme o artigo $146, \S 1^{\circ}$ do CPC, "determinará a autuação em apartado da petição e, no prazo de 15 (quinze) dias, apresentará suas razões, acompanhadas de documentos e de rol de testemunhas, se houver, ordenando a remessa do incidente ao tribunal" (BRASIL, 2015).

Ao ser remetido ao tribunal, o relator irá declarar os seus efeitos, caso o incidente seja recebido sem o efeito suspensivo o processo voltará a tramitar, mas se com efeito suspensivo o processo continuará suspenso para o julgamento do incidente. $E$ "enquanto não for declarado o efeito em que é recebido o incidente ou quando este for recebido com efeito suspensivo, a tutela de urgência será requerida ao substituto legal", conforme o artigo 146, § 3 do CPC (BRASIL, 2015).

A exceção poderá ser arquivada, se não tiver fundamento legal, ou julgada procedente, hipótese em que o juiz será condenado nas custas e o processo será remetido ao substituto legal, podendo o juiz recorrer da decisão.

E caso seja identificado o impedimento ou a suspeição, o Tribunal irá fixar o ponto a partir do qual o magistrado não deveria ter atuado, observando-se que será decretada a nulidade dos seus atos se esses foram realizados quando já presente a causa de impedimento ou de suspeição.

Ademais, o artigo 148 do CPC estabelece que também se aplicam as causas de impedimento e de suspeição "I- ao membro do Ministério Público; II - aos auxiliares da Justiça e III - aos demais sujeitos imparciais do processo" (BRASIL, 2015).

\section{A CONTAMINAÇÃO DO JUIZ PELA PROVA ILÍCITA}

As provas são essenciais no processo, uma vez que possibilitam a comprovação das alegações das partes e, ainda, colaboram para o convencimento do julgador. Se, no entanto, a prova for considerada ilícita, por ser contrária à norma do ordenamento jurídico, não poderá ser utilizada no processo.

Apesar de a prova ilícita não ser utilizada no processo, o juiz, ao ter contato com ela, será contaminado consciente ou inconscientemente pelo conteúdo dessa prova.

Esse fenômeno é conhecido como propensões cognitivas que consiste em uma contaminação cognitiva do magistrado produzida durante o processo, que inevitavelmente compromete o bom julgamento. Com isso, a imparcialidade do julgador é extremamente afetada e isso poderá comprometer as decisões que serão proferidas no processo. Sobre a imparcialidade, Cintra, Grinover e Dinamarco esclarecem:

A imparcialidade do juiz é uma garantia de justiça para as partes. Por isso, têm elas o direito de exigir um juiz imparcial - e o Estado, que assumiu a responsabilidade do exercício da função jurisdicional, tem o correspondente dever de agir com imparcialidade na solução das causas que the são submetidas (2014, p. 71).

Desse modo, a contaminação do juiz pela prova ilícita não afeta apenas sua imparcialidade, mas também a garantia de justiça para as partes, pois uma vez que a imparcialidade é comprometida, por consequência a justiça das decisões proferidas também será comprometida. Nesse sentido, Marinoni, Arenhart e Mitidiero destacam que:

Não se quer dizer, note-se bem, que o juiz que se baseou na prova ilícita irá buscar uma sentença de procedência a qualquer custo, ainda que existam outras provas válidas, mas apenas que a valoração dessas outras provas dificilmente se livrará do conhecimento obtido através da prova ilícita (2016, p. 337).

Assim, mesmo que a prova ilícita não seja usada no processo, o convencimento do juiz pode ter sido influenciado pelo contato com essa prova, o que compromete profundamente as futuras decisões.

Desse modo, o juiz contaminado pela prova ilícita está suspeito, pois haverá uma dúvida quanto à sua imparcialidade. Nesse caso, a parte interessada deverá alegar a suspeição, pois esta consiste em uma nulidade relativa que necessita de provocação da parte. 


\section{Direito \\ Debate}

TEORIA DA DESCONTAMINAÇÃO NA JURISDIÇÃO SUSTENTÁVEL E PROVA ILÍCITA

Magno Federici Gomes - Letícia Alves de Oliveira

Como isso, a contaminação do juiz pela prova ilícita tem repercussão somente para a parte, que suspeita que o juiz teve sua imparcialidade comprometida pela prova ilícita. Isto porque a contaminação do juiz pela prova ilícita afeta a sua imparcialidade, o que influencia as decisões proferidas no processo, uma vez que o juiz não se desvincula das informações que tomou conhecimento por meio da prova ilícita.

Ademais, caso seja proferida sentença baseada em prova ilícita, esta deverá ser afastada, e essa decisão tem o efeito de descontaminar o julgado; a tal fenômeno dá-se o nome de teoria da descontaminação do julgado. Nesse sentido, Marinoni, Arenhart e Mitidiero destacam que:

Trata-se de situação que é peculiar à natureza humana, e, assim, algo que deve ser identificado para que a descontaminação do julgado seja plena, ou para que a sua descontaminação pelo tribunal elimine - ou previna - qualquer possibilidade de infecção posterior. Portanto, se o tribunal decide que uma das provas em que a sentença se baseou é ilícita, o julgamento de primeiro grau deverá ser feito por outro juiz, que não aquele que proferiu a sentença anterior (2016, p. 337).

Na hipótese descrita, deverá ser proferida outra decisão de $1^{\circ}$ grau, mas por outro juiz, pois o magistrado que proferiu a sentença baseada em prova ilícita foi contaminado por essa prova e teve seu convencimento influenciado.

Com isso, percebe-se a complexidade da contaminação do juiz pelo contato com provas ilícitas, pois não se pode afirmar que o magistrado irá conduzir o processo e proferir decisões baseado na prova ilícita, mas, caso isso ocorra, a correta aplicação do Direito estará seriamente comprometida.

Diante disso, havendo o contato do juiz com prova ilícita, e mesmo que esta não seja utilizada no processo, o juiz será contaminado consciente ou inconscientemente e terá sua imparcialidade afetada. Assim, o juiz contaminado pela prova ilícita não poderia mais conduzir o processo, e ele próprio pode reconhecer sua suspeição por foro íntimo ou uma das partes por meio de arguição de suspeição (artigo 146 do CPC/15). Se, no entanto, nenhuma dessas hipóteses ocorrerem, os atos praticados pelo juiz contaminado se aperfeiçoam e passam a ser considerados válidos.

\section{CONSIDERAÇÕES FINAIS}

As provas no processo judicial têm extrema importância, destacando-se que a questão das provas ilícitas e a contaminação do juiz pelo contato com elas é um problema sério que prejudica a formação das decisões judiciais. Como inerentes ao tema, tem-se os princípios da isonomia, do juízo natural, do devido processo legal, do contraditório e da vedação das provas ilícitas.

A prova é um direito fundamental, que tem por objetivo a comprovação das alegações das partes, o que colabora para o convencimento do julgador. E quanto à apreciação das provas, elas serão analisadas conforme o sistema de persuasão racional na sua apreciação, que permite a livre análise, mas vincula tal apreciação aos fatos e circunstâncias contidos no processo e, ainda, exige a indicação na decisão das razões da formação do convencimento.

No caso das provas ilícitas, elas não devem ser utilizadas no processo em razão da vedação constitucional, artigo $5^{\circ}$, inciso LVI, da CF/88, e legal, artigo 369, do CPC/15. Destaca-se que no processo penal e no processo civil as provas estão submetidas à mesma vedação constitucional. No processo penal, conforme artigo 157 do CPP, tem-se a vedação das provas ilícitas que devem ser desentranhadas do processo e, ainda, além do controle da atuação policial para se evitar condutas abusivas, a vedação a provas ilícitas também objetiva proteger o direito de liberdade diante do poder punitivo do Estado. No processo civil, ocorre a ponderação entre o direito material tutelado e o direito material violado pela prova ilícita, para que se obtenha decisões mais justas e adequadas.

Destaca-se a essencialidade da imparcialidade do juiz para a justiça das decisões, ressaltando-se que sua ausência pode causar prejuízo às partes, e também à aplicação do Direito. Em razão disso, o CPC/15 prevê nos artigos 144 e 145 as hipóteses de impedimento e suspeição, que possibilitam o afastamento do juiz parcial. O impedimento e suspeição afetam a imparcialidade do juiz e, por consequência, impedem a igualdade de tratamento das partes e a justiça das decisões. 
A imparcialidade do julgador também é afetada pela prova ilícita. Mesmo não sendo utilizada no processo, o juiz, ao ter contato com ela, será contaminado consciente ou inconscientemente pelo conteúdo dessa prova irregular. Assim, a imparcialidade do julgador, ao ser afetada, poderá comprometer as decisões que serão proferidas no processo, pois o magistrado não se desvincula das informações que tomou conhecimento por intermédio da prova ilícita.

Em razão disso, o juiz contaminado pela prova ilícita torna-se suspeito, pois haverá uma dúvida quanto a sua imparcialidade. Nesse contexto, o juiz contaminado em razão do contato com uma prova ilícita não poderia mais conduzir o processo, e o próprio magistrado pode reconhecer sua suspeição por motivo de foro íntimo ou uma das partes por meio de arguição de suspeição. Se, todavia, nenhuma dessas hipóteses ocorrerem, os atos praticados pelo juiz contaminado se convalescem, tendo em vista se tratar de nulidade processual relativa.

Dessa forma, para que se evitem as consequências gravosas causadas pela contaminação do juiz pelo contato com provas ilícitas, os princípios devem ser respeitados pelos sujeitos processuais para que haja uma correta aplicação do Direito e decisões mais justas e equânimes.

\section{REFERÊNCIAS}

BODNAR, Zenildo. Os novos desafios da jurisdição para a sustentabilidade na atual sociedade de risco. Revista Veredas do Direito, Belo Horizonte, v. 6, n. 12, p. 101-119, jul./dez. 2009. Disponível em: http://www.domhelder.edu.br/revista/index.php/ veredas/article/view/19/134. Acesso em: 20 ago. 2019.

BRASIL. Código de Processo Civil (2015). Lei no 13.105, de 16 de março de 2015. Código de Processo Civil. Diário Oficial da União, Brasília, 17 mar. 2015. Disponível em: http://www.planalto.gov.br/ccivil_03/_ato2015-2018/2015/lei/l13105.htm. Acesso em: 1ำ nov. 2017.

BRASIL. Código de Processo Penal (1941). Decreto-Lei no 3.689, de 3 de outubro de 1941. Código de Processo Penal. Diário Oficial da União, Brasília, 13 out. 1941. Disponível em: http://www.planalto.gov.br/ccivil_03/decreto-lei/del3689compilado. htm. Acesso em: 16 abr. 2019.

BRASIL. Constituição da República Federativa do Brasil. Brasília: Senado Federal, Centro Gráfico, 1988.

CINTRA, Antônio Carlos de Araújo; GRINOVER, Ada Pellegrini; DINAMARCO, Cândido Rangel. Teoria geral do processo. 20. ed. São Paulo: Malheiros, 2014.

DIDIER JR., Fredie; BRAGA, Paula Sarno; OLIVEIRA, Rafael Alexandria de. Curso de direito processual civil: teoria da prova, direito probatório, ações probatórias, decisão, precedente, coisa julgada e antecipação dos efeitos da tutela. 10. ed. Salvador: JusPodivm, 2015. V. 2.

GOMES, Magno Federici; DRUMOND, Letícia. A efetividade e as recentes alterações legislativas no Código de Processo Civil: princípios constitucionais do processo civil e modificações normativas anteriores à Emenda Constitucional no $45 / 2004$. Belo Horizonte: Puc Minas Virtual, 2012. V. 1.

GOMES, Magno Federici; FERREIRA, Leandro José. A dimensão jurídico-política da sustentabilidade e o direito fundamental à razoável duração do procedimento. Revista do Direito, Santa Cruz do Sul, v. 2, n. 52, p. 93-111, maio/ago. 2017. Disponível em: https://online.unisc.br/seer/index.php/direito/article/view/8864. Acesso em: 20 ago. 2019

GRECO FILHO, Vicente. Direito processual civil brasileiro: teoria geral do processo a auxiliares da justiça. 20. ed. São Paulo: Saraiva, 2007. V. 1.

GRINOVER, Ada Pellegrin; FERNANDES, Antônio Scarance; GOMES FILHO, Antônio Magalhaes. As nulidades do processo penal. 9. ed. São Paulo: Revista dos Tribunais, 2006.

MARINONI, Luiz Guilherme; ARENHART, Sérgio Cruz; MITIDIERO, Daniel. Novo curso de processo civil: tutela dos direitos mediante procedimento comum. 2. ed. São Paulo: Revista dos Tribunais, 2016. V. 2.

NUNES, Dierle et al. Curso de direito processual civil: fundamentação e aplicação. 2. ed. Belo Horizonte: Fórum, 2013.

PEGORARO JUNIOR, Paulo Roberto. Imparcialidade como direito processual fundamental: impedimento e suspeição no novo Código de Processo Civil. In: LEITE, George Salomão; STRECK, Lênio; NERY JUNIOR, Nelson (coord.). Crise dos poderes da República: Judiciário, Legislativo e Executivo. São Paulo: Revista dos Tribunais, 2017. p. 397-411. Disponível em: https://www.academia.edu/34055721/Imparcialidade_como_direito_processual_fundamental_impedimento_e_suspei\%C3\%A7\%C3\%A3o_no_ novo_C\%C3\%B3digo_de_Processo_Civil. Acesso em: 27 dez. 2019.

PEIXOTO, Ravi (org.). Enunciados: Fórum Permanente de Processualistas Civis. Salvador: JusPodivm, 2018.

SILVA, De Plácido e. Princípios. In: SILVA, De Plácido e. Vocabulário jurídico. 11. ed. Rio de Janeiro: Forense, 1993. p. 447. V. 3. 